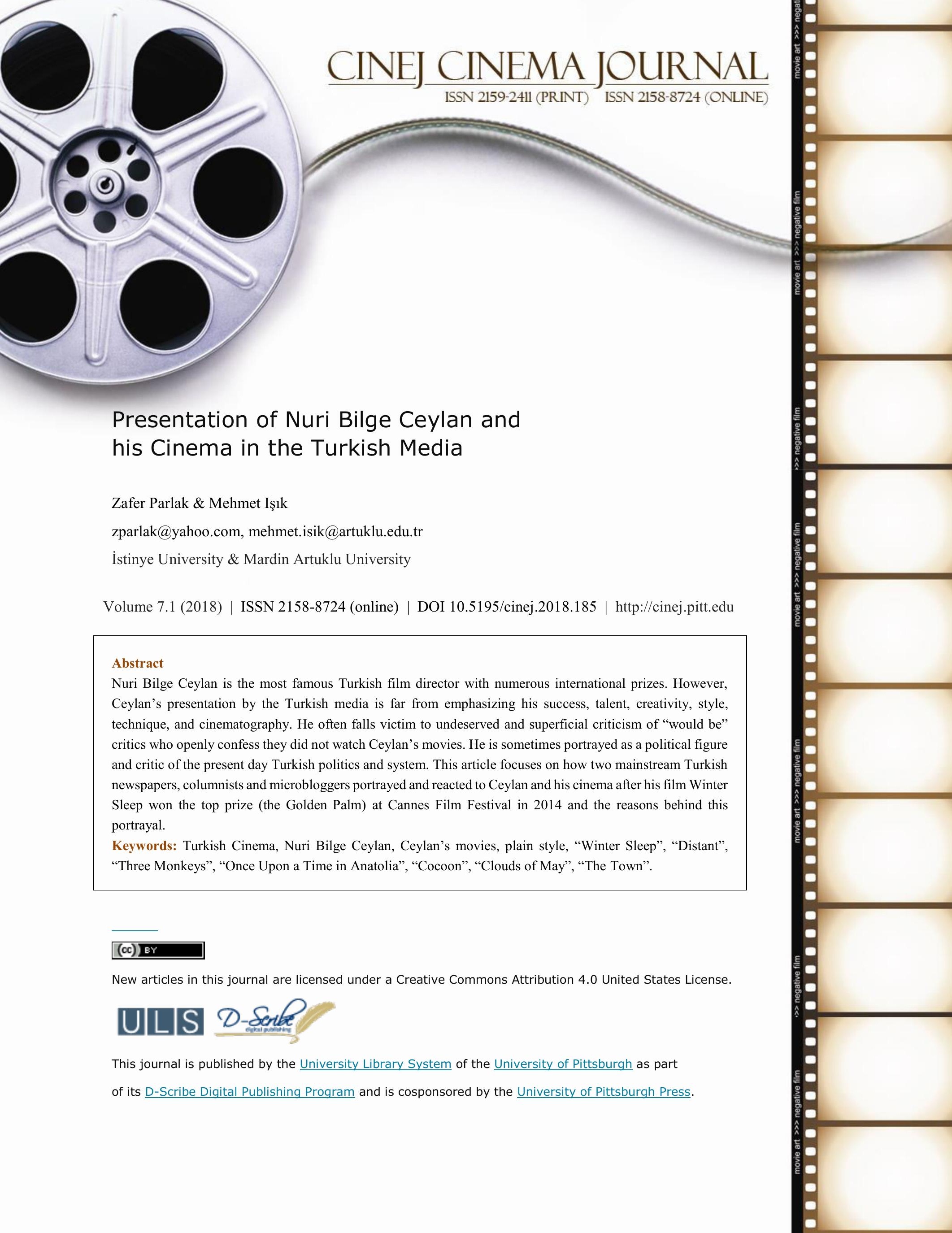




\section{Presentation of Nuri Bilge Ceylan and his Cinema in the Turkish Media}

\section{Zafer Parlak \& Mehmet Işık}

\section{Introduction}

Value of art and artists has been an issue of ongoing debate in Turkey. It is often argued that artists and especially "genuine" artists can hardly be popular and receive the respect they deserve. Mass media mainly focuses on tabloidizing artists and their achievements along with their private lives. Even though there is no agreement on the qualifications to distinguish between "genuine" and other artists, almost everybody blames mass media for under- and misrepresentation of "genuine" artists.

Despite this widespread criticism, there is little academic research on the presentation of artists in mass media. During our research, we have not encountered any academic works that focus on how artists that brought international prizes to Turkey in the field of cinema, painting, music, sculpture, ceramics, architecture etc. are/were represented in main stream mass media in Turkey. When the Turkish cinema celebrated its one hundredth anniversary in 2014, Nuri Bilge Ceylan, a renowned Turkish film director with who had proven his value with numerous international prizes, gave Turkish cinema a great gift: the Golden Palm. Our research concentrates on Ceylan's presentation in the Turkish media and microblog sites especially after he won the Golden Palm.

Media is an important tool influencing perceptions, attitudes and behaviors of individuals and masses. News reports and comments on "genuine" artists may affect opinions of the public. The main aim of this study is to elaborate on how Ceylan, one of the most successful film directors of the present day Turkish cinema, is perceived and presented in the mainstream Turkish media. 
The Internet is the leading communication media of our time as it provides its users with the opportunity to express their feelings and ideas in a relatively free way. In addition, it is an important tool for individuals to interact with their peers and learn about some specific topics. Examination of ideas and thoughts of young Turkish Internet and micro blog users can provide a reliable starting point to determine how people perceive the media presentations of Ceylan and his cinema. Therefore this article also focuses on the thoughts and ideas of a certain group of microbloggers. The study uses discourse analysis to explore how the contents about Ceylan and his cinema are displayed and presented within the selected media. Also mini blog entries are analyzed via discourse analysis. By focusing on the presentation of Ceylan in Turkish media, we also aim to drawconclusions on the reasons for low and shallow presentation of "genuine" artists in the Turkish mass media.

\section{Nuri Bilge Ceylan and his Cinema}

Ceylan was born in Istanbul in 1959. Following his graduation from the department of electric engineering at Boğaziçi University, he studied cinema at Mimar Sinan University, Faculty of Fine Arts for two years. (Wood 2006, p.20; Pay 2009, p.72). He started photography at the age of fifteen and some of his portfolios were published in prestigious art magazines, such as Gergedan (Rhinoceros) in 1980s many years before he started cinema (Wood 2006, p.21; Hakan 2009, p.474). In 1989, a series of his photographs were published in Argos under the title of Çılak ve Deniz (The Naked and the Sea) (Tosun 2005a, p.256).

Ceylan started cinema as a director with his twenty-minute, black-and-white short film Koza (Cocoon) in 1995 (Suner 2006, p.105). This black and white film shed light to lives of an estranged elderly couple. It was enacted by Ceylan's own parents and received warm reception at 
the 48th Cannes Film Festival (Dönmez-Colin 2014, p.92). After Cocoon, Ceylan shot his first featured movie Kasaba (The Town) in 1997. This predominantly autobiographical movie is the story of a family living in a small and relatively closed town in Anatolia, Turkey, depicted through the eyes of children struggling with pangs of early adulthood. The film participated in several film festivals and received many prizes.

Ceylan received the best director award at Golden Orange Film Festival in Antalya in 1999 with his Mayıs Sikıntısı (Clouds of May). Similar to Ceylan's previous film, The Town, it is an introspective story of a film director who goes back to his hometown to shoot a movie using local people in the cast (Cardullo 2015, p.238). These three films are referred as Ceylan's autobiographical trio of the province, through which he estranges himself from the traditional narrative of Turkish cinema and adopts his peculiar narrative technique.

His movie Uzak (Distant), which focuses on two lonely and estranged cousins, received the Grand Prix at $56^{\text {th }}$ Cannes Film Festival. In 2008, Ceylan received the The Best Director prize at Cannes with $\ddot{U} c ̧$ Maymun (Three Monkeys), which he dedicated to his "lonely and beautiful country" during the prize ceremony. He was the second time winner of the Grand Prix at $64^{\text {th }}$ Cannes Film Festival in 2011 with his Bir Zamanlar Anadolu'da (Once Upon a Time in Anatolia). Klş Uykusu (Winter Sleep) won the biggest prize, the Golden Palm in 2014.

In Ceylan's films province is not presented as a fabulous, fictional, nostalgic and idealized location in the distant past living its innocent social childhood in an age of innocence. Ceylan's perspective of the province is directly related to its present state; he concentrates on whatever has remained or transformed from the province (Suner 2006, p.107). Province, which is a symbol of in-betweennes within the urban/rural dicothomy, evolves into a symbol of closedness and inertia in Ceylan's films. Atlhough province as a concept refers to hope and nostalgia within popular 
cinema, Ceylan manages to transform this feeling to profundity of reality in backwardness of the province (Aytekin 2015, p.249).

Although Ceylan starts his journey from the province with Cocoon, The Town, and Clouds of May, he ends up in the city. In Distant (2002) he establishes a bridge between the rural and the urban. By connecting the province with the city, he discusses denial of the past and change of social class within the life story of a photographer who enters existential crisis after he is deserted by his wife. In İklimler (Climates) (2006) he endeavors to explore and define the multi-dimensional and sometimes self-inflicted problems of intellectuals within the context of a self-centered university professor's relationship with his younger wife. Both Ceylan and his wife Ebru acted in the film as well.

Three Monkeys (Üç Maymun) (2008) deviates from the self-reflexive films of Ceylan. It focuses on the individual and it foregrounds guilt, complicity and oblivion through a family situation (Donmez-Colin, 2014, p.328). Once Upon a Time in Anatolia (Bir Zamanlar Anadolu'da) (2011) is a 157- minute long film about a group of males seeking a dead body. The film won the Grand Jury Prize at Cannes 2011 (Ebert 2013, p.441). Winter Sleep (Kış Uykusu) (2014), the winner of the Golden Palm at the Cannes Film Festival, is about a former actor running a small hotel in a small town in Anatolia and his feelings of dissatisfaction.

Once Upon a Time in Anatolia marks a significant shift in Ceylan's cinematography (Tunalı 2014, p.40). As opposed to his earlier films in which images are predominant, in this film Ceylan endeavors to express his story orally as well (Aytekin 2015, p.259). This shift becomes more visible in Winter Sleep, which includes in-depth character analyses embodied in sometimes incessant monologues. Ceylan differs from numerous prize-winning directors with his low-budget films and avoidance of professional actors and actresses especially in his earlier films. He follows 
a peculiar path which forms his cinematography and is strikingly skilled in creating aesthetic frames thanks to his background as a photographer. He reflects his personal history and imposition to his films within the framework of a minimalist story and environment he creates (Pösteki 2004, p.136).

Ceylan belongs to the young generation of Turkish film directors who created their peculiar methods of narration. His narrative and expression are founded basically upon his plain style. Plots of his films can be summarized with one or two sentences because he deals with a sequence of life rather than stories. He employs slight narrative to achieve his goal. His narrative is loaded with images as well as association and connotation of ideas. Limited movement of cameras, reduced use of music, economized dialogues, amateur cast, low budget, and his prioritizing form over content render Ceylan a minimalist director. (Sözen 2013, p.160).

Plainness is one of the leading peculiarities of Ceylan's narrative. He avoids complicated plots and just focuses on life itself. He gives priority to expressing the plain truth with no additions and as naturally as possible. He avoids transforming or recreating the truth. Everything is just like in real life, with no minuses or pluses. This requires a plain and unmoving narrative, which is close to photographic recording of life as in still images. This can be conceptualized as Ceylan's devotion to the instance and all it encompasses. In Ceylan's movies, instances and frames refer to a certain period in one's life. What they later accumulate into displays Ceylan's narrative not with overt words but with people, gestures, and images. Thanks to his background as a photographer, Ceylan's narrative is founded upon imagery. Almost every frame of his films includes portraits. In Distant, for instance, protagonists look towards the city they were defeated in and can never become a part of. Several scenes provide the audience with a slow-motion sequence of postcard imagery; unequaled scenes make Istanbul one of the main actors of the film (Tosun 2005, p.135). 
Ceylan's plain narrative, use of amateur cast, preference of still-life images, simple plot and his avoidance of studio shots render Ceylan a minimalist director and amplify the value of the change he introduced to Turkish cinema. Although he prefers to remain faithful to the scenario, while shooting his films he does not disregard new ideas and impromptu alternatives and he incorporates them to his films. His impromptu attitude seasons his movies with a fresh feeling of credibility (Scognamillo 2003, p.432).

Dialogs and sound have minimal place in Ceylan's earlier films. Characters speak in low tone. He is highly cautious and reserved about use of music, and he almost excludes music to impress the audience (Daldal 2003, p.259). To a certain extent he resorts to autobiographic elements, prefers slight narrative, relies on plain performance of amateur cast, separates sound and image, provides chronological ambiguity, and gives priority to image in narrative. He adapts the rules of old cinema to his own needs, vision and expectation; thus hecreates a peculiar example of a director and his cinema (Akbulut 2005, p.44). In addition to their themes, Ceylan's films are distinguished with their plain techniques. Ceylan allows no artificiality in his movies; therefore he prefers plainness and simplicity in his narrative technique. As he does not resort to fast and sudden camera movements, the audience is almost unaware of the camera throughout the film.

His employment of amateur cast is a result of his search for naturality. It is as if he asks the cast not to act. He expects everything to be as natural as in real life, which is why he employs people from his immediate surrounding including his family, relatives and friends. He dislikes artsy and exaggerated acting. By reducing sound as much as possible, he brings imagery to the foreground. By minimizing setup, he tries to prevent artificiality. He keeps a distance with employment of music to intensify feelings, enrich and deepen narrative. He sees music as a trap, therefore he minimizes it in his films (Tosun 2005, p.136). 
Ceylan uses the camera very close to his characters to create the intended meaning and underline certain feelings and remarks. Close-ups are intended to be visual expressions of the unspoken and unuttered feelings that fill the scene. Close-ups of faces are frequently used to disclose the inner world of characters in combination with long silences. Although they cannot surface at oral plane, feelings of being entrapped are reflected at visual level thanks to close-ups and lighting (Sözen 2013, p.161).

Ceylan's films do not absorb and entrap the audience in timeline and location. Instead they call the audience to participate through a loose knitting of time and location. Ceylan employs especially long "gaps" to prevent the audience from focusing only on the narrative. He thus invites the audience to fill the gaps with their own recollections and associations borne of their own memories. This is how long gaps enable the audience to experience real life situation through participation (Özy1lmaz 2007, p.133).

In short, narrative technique of Ceylan's cinema follows a path starting from photographic narrative and moving towards oral narrative. In Cocoon, The Town (also known as The Small Town) and Clouds of May photographic narrative is highly visible. Starting with Distant, Ceylan prefers oral narrative which becomes more apparent in each one of his later films. This transformation does not necessarily indicate Ceylan's distancing himself from realistic discourse and techniques. It rather hints that Ceylan turns his camera, which is in quest of truth, from nature to human beings, and to modern and alienated urban or rural misfits.

Since his participation in the Cannes Film Festival in 1995 with his short-movie Cocoon, Ceylan has been a focus of attention in international cinema circles due to his unusual plain narrative technique, his use of visual patterns based on photographic realism, and his introvert and modest personality (Daldal 2003, p.255). Given the multitude of prizes he received, Ceylan 
automatically becomes a figure of media attention. However, presentation and coverage of Ceylan and his cinema in mass media is far from doing service to his accomplishments as an artist.

\section{Methods}

This article seeks how Ceylan and his accomplishments were perceived and presented in mainstream Turkish media as well as mini blogs, written by urban, well-educated young Turks. To do this, first a thematic analysis of the news on Ceylan and his films is made to show how their meaning was formed and received. Next, discourse analysis is used to explore how the content was displayed and presented within selected media; finally content analysis is used to draw a conclusion. This article also explores how and what kind of discourse is developed depending on the dominant themes concerning Ceylan and his cinema. Finally, it also seeks answers to how Ceylan and his cinema are placed within that discourse and what kind of meanings are constructed within the discourse of the media under examination.

This research covers news about Ceylan and his cinema in the websites of three mainstream Turkish newspapers (Hürriyet and Cumhuriyet) within 2014 as well as comments and entries in Ekşisözlük, a popular microblog site. Hürriyet was chosen as the representative of mainstream liberal, populist media. Cumhuriyet, was chosen as it is read mainly by intellectuals interested in arts. Ekşisözlük, a very popular microblog site, was preferred as its entry writers represent and appeal to the "educated" and "progressive" Turks whose voice is often unheard in the mainstream media.

Ceylan is one of the leading representatives of creative director cinema in Turkey (Teksoy 2007, p.104). Our research explores how Ceylan and his cinema are defined by mass media and if this definition maintains a perspective that is sensitive to art and artists. We aim at displaying how 
media presents news on Ceylan and his cinema as well as the problems inherent in this presentation.

\section{Findings Obtained from Analysis of Newspaper Coverage}

Our analysis indicates that Turkish media has not shown due interest to Ceylan and his cinema. In our analysis we focused on the news during 2014, which was the year Ceylan won the Golden Palm. In 2014, Hürriyet published 108 and Cumhuriyet published 60 news on Ceylan with a total of 168 . As majority of the news were only short references to Ceylan and his cinema, it is safe to coclude that the Turkish media did not have much interest in Ceylan that brought the Golden Palm to Turkish cinema that celebrated its one hundredth anniversary in 2014.

Moreover, news on Ceylan and his cinema are problematic not only in quantity but also in quality. We have found out that the coverages lack in-depth background analyses that are based on research and relate Ceylan's films to other issues. We also noticed that they are superficial and present on the spot information for daily consumption.

Of the 108 news in Hürriyet, only 20 provided background information and 10 of them refer to only Ceylan's previous prizes. This was 16 in Cumhuriyet. In other words, 80 percent of the news in our research were devoid of any background information; which means they did not provide information on the causes that led Ceylan to victory and numerous prizes. Shallowness of the presentations tend to cut Ceylan's cinema and art off from their economic, social, political and cultural context and reduce them to a simple success story.

Contents of the news were not free from problems either. As expected, almost all of the news were about Winter Sleep. However, the news mainly delved on the length of the film, which made it "difficult to watch" and "boring", and they gave almost no reference to the value of the prize it won. 
Akif Beki underlines the length of the movie, calls it stagnant and criticizes the "unending dialogues": "After watching the film for two hours you feel that you can fill everything into two hours. The plot is so stagnant, going nowhere. The film does not have a linear flow; instead it is vertical and focuses on the same spot" (Hürriyet 2014, June 1). Onur Baştürk (2014, June 13) agrees with Beki on the length of the film but he defends that the tension of the movie is very high and prevents boredom. He, too, points out that the characters in the film talk too much and dialogues are too lengthy. Although he complains about some characters "that talk endlessly, just like machine guns", he also recommends the audience that their bias with the length should not prevent them from enjoying the film.

As opposed to big budget films, Ceylan embraces a minimalist approach, which leads him in his quest for perfect narration and thus forms his cinema. This also accounts for why average moviegoers find his films "boring" or even "unbearable" at times. Ceylan's cinema is deliberate and planned. He does not follow paths trodden by others. He is not preoccupied with commercial success of his films; he is in favor of cinema for art. His pursuit is for promotion of cinema as an art and he does this without estranging and alienating his potential audience. Although he is concerned with reflecting life as it is, he is ready to undertake everything he desires to do. As opposed to big budget products of big capital film industry, he prefers low budget film s and thus embraces a dissident stance. However, mainstream media fails to realize Ceylan's philosophy and is far from presenting a realistic portrayal of him and his cinema. They tend to equate quality of a film only with its ticket box success and the number of its audience, therefore they often present him as a director who needs audience. 
This problematic approach is manifest in the news that compare Ceylan's Winter Sleep with Şahan Gökbakar's Recep Ivvedik ${ }^{l}$, which is a ticket box hit. Hürriyet compared ticket box successes of Winter Sleep with Recep Ivedik 4 which attracted millions of audience to cinemas. In the first week, the latter's audience was thirty-three times more than the former (2014, June 17). Four months later, Recep Ivedik 4 had been watched by almost 3.8 million people, which was almost 20 times more than the audience of Winter Sleep. While Ivedik was the most watched film of 2014, Winter Sleep had the $36^{\text {th }}$ place in the listing. (Hürriyet 2014, October 28).

Even news that criticizes the people focusing on the length of the film consolidates the claim that Ceylan is a director without audience. On the one hand Ceylan is praised as a director that regularly wins not only international prizes but also hearts of prominent members of juries. On the other hand, even the tributes themselves somehow downgrade Winter Sleep when they refer to the general impression of average audience.

Almost six months after Winter Sleep won the Golden Palm, Cumhuriyet (2014, November 2) voiced its concern about the small number of the audience that watched the film and have a taste for films of artistic value: “How many people have watched Ceylan's films so far despite the prizes he won?"

In news and their presentation, identity of experts is as crucial as their views and comments. In our research, we found that all the commentators were either related to cinema or were people of fame. In newspapers, there is no reference to the views of mainstream audience.

Hürriyet (2014, June 12) presents a wide panorama of views of Turkish film critiques and columnists that unanimously praise Ceylan and his success. According to Alin Taşçıyan, chair of

\footnotetext{
${ }^{1}$ Recep Ivedik is an oversize, rude, uneducated, unemployed anti-hero trying to fit into changing social norms, secure his place in the lower middle class and aspiring for a place in the middle class. He is a critique of rapid social and economic changes. There are four İvedik movies, all of which were ticket box hits and are still shown on several TV channels regularly.
} 
SIYAD (Association of Film Producers), Winter Sleep is a "restoration"; Ömür Gedik of Hürriyet calls it as "Ceylan's most talkative film"; Nil Kural of Milliyet praises it as a "panorama of Turkey"; Kerem Akça of Habertürk sees the film as an "allegory of present day Turkey"; Atilla Dorsay of $T 24$ points out that Ceylan has now "a rendez-vous with literature"; Cüneyt Cebenoyan refers to the length of the film and says "He [Ceylan] could make two 100-minute films out of Winter Sleep." Others avoid any criticism of the film and focus on the plot and the issues it deals with. Eylem Kaftan of Vatan believes that the film will force the audience to an inevitable confrontation with their own painful truth. Kaya Özkaracalar of Sol (The Left) -a leftist newspapersays Ceylan "really deserved the prize"; Furat Yücel of Altyazı (Subtitle) praises the feeling of past and its treatment as "outstanding"; Murat Şahin of sinemamuzik.com calls Ceylan as "the painter of our unhappiness"; Kaan Karsan of Beyazperde.com (silverscreen) hails it as a "symbol of perfection"; Murat Özer of Arka Pencere (Back Window) focuses on the theme: "From hatred of classes to intrigues of male-female relationship." Only Çağdaş Günerbüyük of Evrensel newspaper is ambivalent: "I am not sure if the film is a successful and thorough exploration of deep feelings it deals with." (Hürriyet 2014, June 12).

Hürriyet shares views of foreign critics as well. According to Derek Malcolm of Evening Standard the film is a revelation of Ceylan's masterhood, and despite its length and numerous over-talkative characters, it is much closer to the audience than his earlier films. He likens Ceylan to Chekhov in terms of picking mundane topics and crafting them to display the chaotic nature of humanity. Justin Cheng of Variety (USA) exalts it as an "incredible masterpiece" that focuses on multifarious examination of frailties of human beings. He comments that if Chekhov had shot a film it would have been very similar to Winter Sleep. Michel Ciment of Positif (France) calls it a masterpiece that was unprecedented since Bergman (Hürriyet 2014, June 14). 
Our analysis has shown that some popular singers, fashion models or TV stars employ a language that downgrade Ceylan's films even though they confess they have not watched any of them. Demet Akalın, a fashion model, says she is proud of Ceylan, but declines from watching Winter Sleep as she has heard the film is longer than three hours: "Honestly speaking, I am not knowledgeable about paintings or films of art. I do not read; if I wonder about a book, I just go to a bookstore and just read its back pages and cover, and leave it there.” (Hürriyet 26 May, 2014).

Similarly, in his comparison of Winter Sleep with Recep Ivedik, Bület Arınç -Turkey’s former vice prime Minister- points out that there is and should be a distinction between quality and rating, and that the former should overweigh the latter. However, as he congratulates Ceylan he also notes that he, too, sometimes watches Recep Ivedik series, although he is not necessarily a fan of that anti-hero (Cumhuriyet 2014, July 10).

Nomination of Winter Sleep for the Oscar prize has been an issue of controversy. Majority of news present the nomination as a right decision. Majority of the news cover technical details and revolve around the film 's success; however, except for interviews, it is almost impossible to find news that provide in-depth analyses of the reasons that brought Ceylan's success. Presentation of the news is almost in the same format, which makes them repetitive and boring. Turkish media provides wide coverage for success stories of international scope especially in fields of sports, fashion, music, science and medicine. It often declares them as objectification of national pride and prowess. Surprisingly, it adopts a cautious language in celebrating Ceylan and his success. It is almost impossible to see the same words of excitement and celebration used in other news. There is also no reference to the causes that paved the way for Ceylan's international success.

As he himself often emphasizes too, Ceylan is a director that avoids dealing with contemporary political issues. However, when he dedicated the Golden Palm to the youth that lost their lives during Gezi protests in Istanbul in 2013, as well as to the 301 coal miners who died in 
an accident in Soma in May 2014, this was taken as a deviation from his apolitical stand and found wide media coverage.

That Hürriyet did not refer to the coal miners and focused only on the youth that died during Gezi protests is noteworthy. The coal mine accident in Soma that claimed 301 lives coincided with the gala viewing of Winter Sleep in Istanbul. While the family picture was being taken, the cast wore black ribbons and raised placards bearing the word "Soma". The reception was cancelled as part of national mourning. Hürriyet (2014, May 16) just reported the reaction of Ceylan and the cast. It referred to Ceylan's dedication of the film to the Turkish youth that lost their lives in the last year and to the victims of the coal mine accident. Cumhuriyet (2014, May 31) interpreted Ceylan's remarks as follows:

Ceylan believes that an artist can do his best when he is totally free. It is for this reason that he dedicated his prize to the Turkish youth that paid a high price for their quest for freedom with their lives, as well as to coal miners that were compelled by the merciless and wild capitalism to bury their liberty and future under hundred meters of soil.

Messages in Ceylan's speech during the prize ceremony challenged the conviction that Ceylan and his cinema were apolitical. Hürriyet referred to this speech and asked a question: "Does Ceylan's cinema have political aspects?" Instead of giving a direct answer, it gave examples of Ceylan's political discourse. In 2008, when he received the best director prize at Cannes with Three Monkeys, Ceylan dedicated the prize to his "lonely and beautiful country", which was taken as his first "official" social message. Printed and visual media that had disregarded him until then carried him to headlines. During Gezi events, Ceylan sent tweets that announced his disapproval of the government's reaction to the protestors (Hürriyet 2014, July 16). 
Turkish film director, actor and screen writer Yılmaz Güney had shared the Golden Palm with Costa Gavras, a Greek director, in 1982. During the prize ceremony he raised his right fist above his head. Thirty-two years after this event, Ceylan had a similar pause during the photo taking event, which the media found very significant. Presentation of this similarity was based on establishing continuity and parallelism between the two directors who did not have the same political stands. Hürriyet found Ceylan's pose with his right fist up as a significant replica of Güney's stand and carried it to headlines as "The same pause after thirty-two years." (Hürriyet 2014, May 26). A few days later Ceylan noted that he had not planned to raise his right fist and had done it just due to several demands of hundreds of photographers who wanted different poses (Hürriyet 2014, May 30). Cumhuriyet (2014, May 31) focused on establishing parallelism between Ceylan and Güney. It gave reference to Distant, which Ceylan had dedicated to Güney during the prize ceremony at Cannes in 2002: "Although Ceylan says he had not preplanned raising his right fist up, it was obvious that this came automatically as the idea had infused into his subconscious". Both newspapers noted that Ceylan was not displeased with the news that established parallelism between him and Güney. This consolidates the sense of continuity concerning the two directors.

Ceylan's dedication of the prize to the coal miners that lost their lives, the Turkish youth , and his raising of his right fist echoed in the media. Numerous non-governmental organizations, activists and columnists announced their support for Ceylan. A joint declaration of several nongovernmental organizations supported by some opposition parties as well hailed Ceylan as a voice that came from France and comforted millions of people with his salutation of the youth that died since 2013 (Hürriyet 2014, May 26). Taha Akyol (2014, May 26), a prominent columnist of Hürriyet congratulated Ceylan as a person that brought great honor to Turkey with the Golden Palm after Güney, as well as for his indiscriminate sensitivity about deaths of young protestors. Another columnist, Ahmet Hakan (Hürriyet 2014, May 26) compared and contrasted Ceylan and 
Mehmet II, the Ottoman sultan that conquered Istanbul. He emphasized that Ceylan was a person that showed how hearts could be conquered. Hakan asserted that Ceylan conquered thousands of movie theaters across Europe. Hakan also indirectly referred to Turkish politicians that fail to act against visa restrictions towards Turks in Europe. There was also a covert reference to a Turkish high budget blockbuster 1453, which narrated heroic deeds of Turkish conquerors of Istanbul in the year 1453. Ömür Gedik (Hürriyet 2014, May 27) referred to Ceylan as a synthesis of "good education, gentlemanliness, serenity, intelligence, talent, charisma, modesty, patriotism, honesty, straight forwardness, humanism" and many other qualifications and virtues. She hailed him not only for the prize but also for his speech that "came like a tonic" to the Turkish people that had to suffer all sorts of problems in recent days. She wished to see the days that Ceylan's film s would attract the same attention and interest as his speech during the prize ceremony.

Cumhuriyet (2014, March 8; October 22) also underlined Ceylan's political identity by referring to his signing of two declarations prepared by leading members of Turkish film industry. The first was a call against a covert censorship by the Turkish Ministry of Culture and Tourism, and the other was a call for opening a "Humanitarian Corridor" for Syrian refugees fleeing Kobani, signed by Noam Chomsky as well. On the other hand, Hürriyet created a discourse that Ceylan is not watched by the people. It also emphasized that he is a director preferred only by the elite. This is manifest is A. Beki's sardonic criticism (Hurriyet 2014, July 30): “As you know, I have just lost my right to be "an intellectual" by not liking Ceylan's Winter Sleep". An anonymous article in Hürriyet (2014, October 28) pointed out that Winter Sleep had audience especially in central movie theaters of cities, which usually well-educated elite frequented. It said middle and lower class people fighting harsh realities of life and daily economic problems had little interest in and time for elitist problems. 
As Ceylan avoids publicity and prefers invisibility in terms of his private life, there is not much tabloid news about him. However, especially Hürriyet's presentation of the news during shooting of the film and prize ceremony is close to tabloidizing the content through striking headlines that exported from humorous microblog sites: "[Quentin] Tarantino had a fit of jealousy." (Hürriyet 2014, May 26). Another news is about how Haluk Bilginer, Aydın of Winter Sleep, refused Ceylan three times before he accepted acting in the film (Hürriyet 2014, May 31). One coverage was about cold relations between Ceylan and Zeki Demirkubuz, another prize winning and renowned director. The headline was "Is Winter Sleep a cross reference to Demirkubuz?" (Hürriyet 2014, June 23). Another referred to the price of one of Ceylan's photographs (Hürriyet 2014, November 22).

An environmentalist and activist professor's indictment of Ceylan for "mistreatment" and torturing of animals during shooting of Winter Sleep found coverage in three newspapers. They printed Orhan Kural's words of indictment after he delivered his petition to the prosecutor's office (Hürriyet 2014, July 1). Another news was about Ceylan's placing a portable container during the shooting of the film in a location labelled as archeological site. This illegal act, as the newspapers claimed, might require five years in prison (Cumhuriyet 2014, October 5).

\section{Findings Obtained from Analysis of a Microblog Site}

Ekşisözlük (SourTimes or Sour Dictionary) is a very popular microblog site whose writers represent a peculiar group of people. Based on their comments, it is safe to consider that writers of the entries are mainly well-educated, knowledgeable, urban, western-oriented professionals, majority of whom also profess to be progressive. They profess to be open-minded and impartial and avoid aggressive discourse in their comments on pre-defined topics and agenda. Entry writers are required to use nick names, which are usually very funny. 
Entries on Ekşisözlük are fun to read and can be very informative as they represent predominantly views of the educated who tend to have different perspectives and do not find voice in main stream media. Entries on Ekşisözlük can be both humorous and sharp. Some of them somehow end up with criticism of Turkey and Turkish people too. Entries on Ceylan's winning of the Golden Palm reflect the similar approach and include criticism of the current administration. They criticize people that downgrade Ceylan without watching his films. They compare it with Recep Ivedik and thus underline the discourse that Ceylan's films are not watched by majority of Turkish people, Ceylan is elitist, and "genuine artists" are not appreciated.

Under the headline on Ceylan's winning of the Golden Palm there are more than 200 entries of different lengths in 29 pages. None of the entries have any negative reference to Ceylan's victory and all writers receive it as a matter of national pride and they express their worry about low media coverage and expected low interest in the film.

Uyumaz expresses his appreciation by referring to one of Ceylan's words at Cannes prize ceremony: "in your lonely country, there are lonely people that appreciate your achievements". Like many other writers, Posaedon praises Ceylan for winning the Golden Palm, which is "the most prestigious prize of cinema" and which is very unlike the highly commercial Oscar prize. Referring to low media coverage of Ceylan's success and the Turkish prime minister's visit to Germany, Kopuksenaryo says "unfortunately, at most one-fourth of Turkey will be informed about this" and Damien explains the reason: "Turkish TV channels prefer and are forced to broadcast live the discourse of hatred and lies in Cologne, Germany". Ektomorfik too, defends that majority of the Turkish people either will not hear anything about Ceylan or will fail to appreciate what the prize means for Turkey even if they are miraculously informed about it. 
Two bloggers, Sadeli and Humanist Nazi note that Adriana Lima's visit to Turkey or a football match between two Spanish teams found wider coverage than Ceylan's victory. They make it plain that this was a great shame for Turkish media. Although he confesses his dislike for Ceylan's films, Iyilik Yap Pitbull still praises Ceylan and sends his "kind greetings" to the "blind" and degenerate TV channels that disregard Ceylan.

Takma kirpikli huni_emphasizes that Turkish people should be grateful to social media without which Ceylan's success would find no coverage. He also adds that several Turkish museums that received international prizes within a year did not have any coverage in printed media either. As he shares his joy and pride, Huthut states that Ceylan's victory becomes more precious as he won it as a Turk who has to fight and overcome prejudice of Europeans.

Yakarca is certain that Ceylan's film does not have much chance to find movie theaters as especially when "thousands of low quality Turkish films similar to TV-series are on vision.” Nickin ne yabanci expresses his pessimisim by referringto Recep Ivedik: "What difference could Ceylan make even if Ceylan won prizes all over the globe as long as this country has a reality of Recep Ivedik?". Referring to a scene in Recep Ivedik and its popularity, Shed criticizes Ivedik's audience: “Ceylan's success is something that people laughing at Ivedik's farting are not capable of understanding and do not care at all." Oldu mu olmadi points out Turkish people's football craze and how they spend their evenings rejoicing and singing in streets when their team wins, and their total silence about Ceylan's international success. He almost foretells what newspapers will write some weeks later: "This prize ceremony will be of no interest to our mainstream audience, Recep Ivedik will break another ticket box record, we will say that 'a three-hour film is too long,' and we will consume this genius too."

Ceylan is also received as a person who managed to bring hope and a little smile to millions of Turks who are engulfed in total darkness, drowned in an ocean of negative energy, and are in 
desperate need of hope (olur oyle arada,2014). According to Ormankizi3, Ceylan is the sole alive cultural heritage of Turkish cinema. Ayvareceli compares Ceylan's success to that of the Turkish national football team in world cup in 2002 and adds that the overall joy they created is similar.

Political references are very common in Ekşisözlük. The day Ceylan won the prize, the Turkish prime minister was in Germany meeting with Turks living there to secure their votes just two weeks before presidential elections in Turkey. Zeytinyagli notes: "many years later no one will remember the person speaking in Germany today but everybody will always remember the person speaking in France today [Ceylan] as a worthy person". He underlines that art can realize what politics cannot and asks sardonically: "for God's sake, who was the Turkish prime minister the year Yılmaz Güney won the Golden Palm?" Korun adopts a political stand; he dedicates Three Monkeys to the pro-government media for their biased news, Distant to the then prime minister (now the president) of Turkey, and Once Upon A Time in Anatolia to the next generation of Turkish people with the hope that "the murderers will go one day."

According to hya (2014, May 25), Ceylan deserves to be the president of Turkey as he is a person that best understands and tells Turkey. Kolpadanadam_defends that Turkish media's silence about Ceylan and TV channels' live broadcast of the speech of a political leader striving to take Turkey to dark ages should not surprise anybody. Another blogger, Anarsist devlet memuru (An anarchist government official) quotes Hakan Gülseven's article in Yurt (2014, May 26,) that takes Ceylan's remarks as a political message and defends that Turkey is split and there are two Turkeys now: Turkish people have two options: silent approval of the government's corruption, actions and policies based on exploitation of religion or raising [their] heads up and move forward to create a brand new Turkey." 
Some entry writers are disturbed with overpraising of Ceylan's success. They acknowledge his accomplishments but also point out that his dedication of his prize to the Turkish youth does not suffice to declare him a symbol of "national honor." Parrhesiaturkiye_(2014, May 25) satiricially invites people to be proud of Kurtlar Vadisi: Irak (Valley of Wolves: Iraq) ${ }^{2}$ that had "saved Turks' national honor although it was at virtual level". Not all entry writers approve of Ceylan's political discourse. Mucit (2014, May 24) calls Ceylan to dedicate his prize to the "chaos and darkness emanating from Turkish intellectuals [that] failed to embrace and enlighten the Turkish youth and instead provoked them and handed them Molotov cocktails and grenades". Travenian (2014, May 25) complains about misinterpretation of Ceylan's prize speech and underlines that it had no direct reference to the people that died in the coal mine accident in Soma.

In some cases Ceylan was compared to and contrasted with Orhan Pamuk, whose criticism of Turkey on some sensitive issues was not welcomed by many Turks. Denizce (2014, May 25) emphasizes Turkey's thirst for good news, refers to people that demonized Orhan Pamuk -recipient of the Nobel Prize in Literature in 2006- and recommends that people that denigrate Ceylan should undergo urgent psychiatric treatment. Some writers give indirect reference to Orhan Pamuk, Turkish Nobel Prize winner in Literature in 2006 who allegedly "sold his country out to a prize" by criticizing Turkey with her enemies. Nelson nerdela praises (2014, May 25) Ceylan for proving that an artist can win an international prize without selling his homeland away. Tutiyancek (2014, May 25) congratulates Ceylan as an artist that managed to bring a prize to Turkey with a film that did not downgrade Turkey.

\footnotetext{
${ }^{2}$ A popular film about how a group of Turkish renegades revenge on American soldiers that humiliataed Turkish soldiers by hooding them in Iraq in 2004
} 


\section{Conclusion}

Our analyses led us to a conclusion that Turkish media did not give due attention and coverage to Ceylan who brought the Golden Palm to Turkish cinema that celebrated its $100^{\text {th }}$ anniversary in 2014. Except for the news that listed the names of Ceylan's films and the prizes he received, there were limited number of news that provided background information and in-depth analysis of Ceylan's success story. In other words, news that required research and time were sacrificed to those that provided superficial and perishable information. Absence of background information on the factors that brought Ceylan's success isolated him from the artistic, economic and social context of his films, and reduced Ceylan and his cinema to a mere success story. This type of presentation requires bringing the prizes and technical information to the foreground. All of the newspapers in our research just listed the prizes first and added that the number of Ceylan's audience was on the rise.

Newspapers first created a discourse that Ceylan's films are "not easy to watch" and that Ceylan is "a director whose films are not watched". Later they reinforced and recreated the same discourse even when they praised Ceylan and his cinema. This approach materialized further in frequent comparisons of ticket box success of Winter Sleep with the blockbuster Recep Ivedik. What is worse, even those who criticized this approach used the same discourse first, which eventually consolidated and recreated the very discourse they are against. Measuring a director's success with only ticket box success, and when this fails referring to "gradual increase" in the number of the audience contradicts with the critics' intention that seemingly favor Ceylan.

Another discourse was that Ceylan is a director appealing to and watched by the Turkish elite. To support this claim, Ceylan's international prizes were not hailed as Turkey's success story 
but were presented as a proof of Ceylan's elitism. In addition, news about the prizes referred to comments of the elite only, and views of the average audience have not been included.

As he himself emphasizes frequently as well, Ceylan is a director that tries to avoid involvement in daily politics (Ceylan 2011, p.131). Nevertheless, his verbal messages and comments on the coal miners and Gezi protestors as well as his body language during the prize ceremony in Cannes were taken as a sign of his deviation from his apolitical stand.

Entry writers of Ekşisözlük almost unanimously congratulated and praised Ceylan. Their comments tended to be based on knowledge and represented the worldviews of the mainstream elite, whom some critics tend to label as "white Turks."

Both the newspapers and entry writers agreed that "genuine" artists deserve a better place in Turkey and they tended to politicize Ceylan. Many people voiced their opinion without watching Ceylan's films or even reading their synopsis. Whether this is a global tendency or it is something peculiar to the Turkish audience remains to be a question with no definite answer.

\section{BIBLIOGRAPHY}

Akbulut, H. (2005). Nuri Bilge Ceylan Sinemasını Okumak, İstanbul: Bağlam Yayınları.

Andrew, G. (2009, February 6). Interview with Nuri Bilge Ceylan. The Guardian, http://www.guardian.co.uk/film/2009/feb/06/nuri-bilge-ceylan-interview-transcript, Accessed on: 25.01.2016

Aytekin, Pelin E. (2015). Nuri Bilge Ceylan Sinemasının Anlatısal Dönüşümü: Fotoğrafik Anlatımdan, Öyküsel Anlatıma, Selçuk Üniversitesi İletişim Fakültesi Akademik Dergisi, 9(1), 247-265.

Ceylan, N.B. (2011). Meselem İnsan Denen Muammayı ve Onun Bağlı Olduğu Daha da Büyük Muammayı Anlamlandırmaya Çalışmak. (An Interview with Nuri Bilge Ceylan). Mithat Alam 
Film Merkezi Söyleşi ve Panel Y1llı̆̆ı. Retrieved from: http://www.mafm.boun.edu.tr/files/768_7NBC.pdf. Accessed on: 10.01.2016, 120-153.

Cardullo, B. (2015). Film Analysis: A Casebook. Oxford: Wiley Blackwel.

Daldal, A. (2003). Gerçekçi Geleneğin İzinde: Kracauer, Basit Anlatı ve Nuri Bilge Ceylan Sineması, Doğu Batı, 25 (7), 255-273.

Dönmez-Colin, G. (2014). The Routledge Dictionary of Turkish Cinema. New York: Routledge.

Ebert, R. (2013). Roger Ebert's Movie Yearbook 2013: 25th Anniversary Edition. Kansas City: Andrews McMeel Publishing

Güler, H. (2011). Nuri Bilge Ceylan Sineması Üzerine Değerlendirme, Uzak: Kazanan Kaybedenlerin Öyküsü. Ekonomik Yaklaşım, 79 (22), 107-116.

Gülseven, H. (2014, 26 May). İki Türkiye'nin Savaşı. Yurt Gazetesi. Retrieved from http://www.yurtgazetesi.com.tr/...si-makale,8029.html. Accessed on: 05.01.2016.

Kıraç, R. (2000). 90"lı Yıllarda Sinemamıza Genel Bir Bakış. 25. Kare Sinema Dergisi, 30, 12-17.

Pösteki, N. (2004). 1990 Sonrası Türk Sineması. İstanbul: Es Yayınları.

Scognamillo, G. (2003). Türk Sinema Tarihi. İstanbul: Metis Yayınları.

Sözen, M. (2013). Sinemada Anlam Yaratan Bir Öğe Olarak Işık Tasarımı ve Örnek Çözümlemeler, Selçuk Illetişim Fakültesi Dergisi, 7 (4), 152-168.

Suner, A. (2006). Hayalet Ev: Yeni Türk Sinemasında Aidiyet, Kimlik ve Bellek. İstanbul: Metis.

Teksoy, R. (2007). Rekin Teksoy'un Türk sineması. İstanbul Oğlak Yayıncılık.

Tosun, N. (2005). Nuri Bilge Ceylan Sinemas1 ve Uzak, Hece Dergisi, 101, 135-137.

Tosun, N. (2005a). Film Defteri. İstanbul: Dergâh Yayınları. 
Tunalı, D. (2014). Hareketli Durağanlık İzlenimi: Bir Zamanlar Anadolu'da, Yedi Sanat, Tasarım ve Bilim Dergisi, 11, 39-51.

Wood, J. (2006). Talking Movies: Contemporary World Filmmakers in Interview, London: Wallflower Press.

\section{Social Media References}

Anarsist devlet memuru. (2014, May 28) https://eksisozluk.com/nuri-bilge-ceylanin-altinpalmiye-odulu-almasi--4400052?p=1.Accessed on: 03.01.2016.

Ayvareceli. (2014, May 25). https://eksisozluk.com/nuri-bilge-ceylanin-altin-palmiye-odulualmasi--4400052?p=1. Accessed on: 04.01.2016.

Damien Rice Sarkilarinin Hayrani. (2014, May 24). https://eksisozluk.com/nuri-bilge-ceylaninaltin-palmiye-odulu-almasi--4400052? p=1. Accessed on: 03.01.2016.

Denizce. (2014, May 25). https://eksisozluk.com/nuri-bilge-ceylanin-altin-palmiye-odulu-almasi$-4400052 ? \mathrm{p}=1$. Accessed on: 05.01.2016.

Ektomorfik. (2014, May 25). https://eksisozluk.com/nuri-bilge-ceylanin-altin-palmiye-odulualmasi--4400052? p=1. Accessed on: 04.01.2016.

https://eksisozluk.com/nuri-bilge-ceylanin-altin-palmiye-odulu-almasi--4400052?p=1

Humanist Nazi. (2014, May 25). https://eksisozluk.com/nuri-bilge-ceylanin-altin-palmiye-odulualmasi--4400052? p=1. Accessed on: 05.01.2016.

Huthut. (2014, May 25). https://eksisozluk.com/nuri-bilge-ceylanin-altin-palmiye-odulu-almasi-4400052? $\mathrm{p}=1$. Accessed on: 07.01.2016.

hya. (2014, May 25). https://eksisozluk.com/nuri-bilge-ceylanin-altin-palmiye-odulu-almasi-4400052? $\mathrm{p}=1$. Accessed on: 08.01.2016.

Iyilik Yap Pitbull. (2014, May 25). https://eksisozluk.com/nuri-bilge-ceylanin-altin-palmiyeodulu-almasi--4400052?p=1. Accessed on: 05.01.2016. 
kolpadanadam. (2014, May 25). https://eksisozluk.com/nuri-bilge-ceylanin-altin-palmiye-odulualmasi--4400052?p=1. Accessed on: 09.01.2016.

Kopuksenaryo. (2014, May 24). https://eksisozluk.com/nuri-bilge-ceylanin-altin-palmiye-odulualmasi--4400052?p=1. Accessed on: 03.01.2016.

korun parmagina batan goz. (2014, May 24). https://eksisozluk.com/nuri-bilge-ceylanin-altinpalmiye-odulu-almasi--4400052? $\mathrm{p}=1$. Accessed on: 02.01.2016.

Mucit. (2014, May 24). https://eksisozluk.com/nuri-bilge-ceylanin-altin-palmiye-odulu-almasi-4400052? $\mathrm{p}=1$. Accessed on: 07.01.2016.

Nelson nerdela. (2014, May 25). https://eksisozluk.com/nuri-bilge-ceylanin-altin-palmiye-odulualmasi--4400052?p=1. Accessed on: 07.01.2016.

Nickin ne yabanci. (2014, May 25). https://eksisozluk.com/nuri-bilge-ceylanin-altin-palmiyeodulu-almasi--4400052?p=1. Accessed on: 06.01.2016.

Olur oyle arada. (2014, May 24). https://eksisozluk.com/nuri-bilge-ceylanin-altin-palmiye-odulualmasi--4400052? p=1. Accessed on: 07.01.2016.

Ormankizi3 (2014, May 24). https://eksisozluk.com/nuri-bilge-ceylanin-altin-palmiye-odulualmasi--4400052?p=1. Accessed on: 09.01.2016.

Parrhesiaturkiye. (2014, May 25). https://eksisozluk.com/nuri-bilge-ceylanin-altin-palmiyeodulu-almasi--4400052?p=1. Accessed on: 03.01.2016.

Posaedon. (2014, May 24). https://eksisozluk.com/nuri-bilge-ceylanin-altin-palmiye-odulualmasi--4400052?p=1. Accessed on: 06.01.2016.

Sadeli Cubuk Kraker. (2014, May 24). https://eksisozluk.com/nuri-bilge-ceylanin-altin-palmiyeodulu-almasi--4400052?p=1. Accessed on: 07.01.2016.

Shed (2014, May 25). https://eksisozluk.com/nuri-bilge-ceylanin-altin-palmiye-odulu-almasi-4400052? $\mathrm{p}=1$. Accessed on: 03.01.2016. 
Takma kirpikli huni. (2014, May 25). https://eksisozluk.com/nuri-bilge-ceylanin-altin-palmiyeodulu-almasi--4400052? p=1. Accessed on: 02.01.2016.

Travenian. (2014, May 25). https://eksisozluk.com/nuri-bilge-ceylanin-altin-palmiye-odulualmasi--4400052?p=1. Accessed on: 02.01.2016.

Tutiyancek. (2014, May 25). https://eksisozluk.com/nuri-bilge-ceylanin-altin-palmiye-odulualmasi--4400052? p=1. Accessed on: 08.01.2016.

Uyumaz. (2014, May 24). https://eksisozluk.com/nuri-bilge-ceylanin-altin-palmiye-odulu-almasi$-4400052 ? \mathrm{p}=1$. Accessed on: 04.01.2016.

Yakarca. (2014, May 25). https://eksisozluk.com/nuri-bilge-ceylanin-altin-palmiye-odulu-almasi-4400052 ? $\mathrm{p}=1$. Accessed on: 02.01.2016.

Zeytinyagli yemege atilan kup seker. (2014, May 24). https://eksisozluk.com/nuri-bilge-ceylaninaltin-palmiye-odulu-almasi--4400052? $\mathrm{p}=1$. Accessed on: 03.01.2016. 